\title{
Decreased Adrenergic Neuronal Uptake Activity in Experimental Right Heart Failure

\author{
A Chamber-specific Contributor to Beta-Adrenoceptor Downregulation
}

\author{
Chang-seng Liang, Tai-Hwang M. Fan, J. Thompson Sullebarger, and Susumu Sakamoto \\ Cardiology Research Laboratories, Cardiology Unit, University of Rochester Medical Center, Rochester, New York 14642
}

\begin{abstract}
The reduction of myocardial beta-adrenoceptor density in congestive heart failure has been thought to be caused by agonistinduced homologous desensitization. However, recent evidence suggests that excessive adrenergic stimulation may not produce myocardial beta-receptor downregulation unless there is an additional defect in the local norepinephrine (NE) uptake mechanism. To investigate the association between betaadrenoceptor regulation and NE uptake activity, we carried out studies in 30 dogs with right heart failure (RHF) produced by tricuspid avulsion and progressive pulmonary artery constriction and 23 sham-operated control dogs. We determined NE uptake activity by measuring accumulation of $\left[{ }^{3} \mathrm{H}\right] \mathrm{NE}$ in tissue slices, NE uptake-1 carrier density by $\left[^{3} \mathrm{H}\right]$ mazindol binding and beta-adrenoceptor density by $\left[{ }^{3} \mathrm{H}\right]$ dihydroalprenolol binding. Compared with sham-operated dogs, RHF dogs showed a $26 \%$ decrease in beta-adrenoceptor density, a $51 \%$ reduction in NE uptake activity, and a 57\% decrease in NE uptake-1 carrier density in their right ventricles. In addition, right ventricle beta-receptor density correlated significantly with NE uptake activity and NE uptake-1 carrier density. In contrast, neither NE uptake activity nor beta-receptor density in the left ventricle and renal cortex was affected by RHF. Thus, the failing myocardium is associated with an organ- and chamber-specific subnormal neuronal NE uptake. This chamber-specific loss of NE uptake-1 carrier could effectively reduce local NE clearance, and represent a local factor that predisposes the failing ventricle to beta-adrenoceptor downregulation.
\end{abstract}

\section{Introduction}

Human congestive heart failure is associated with an increase in circulating norepinephrine (1-4), increase in myocardial release of catecholamines (5), beta-adrenergic subsensitivity $(2$,

Presented in part at the 1987 Fall meetings of the American Society for Pharmacology and Experimental Therapeutics at Honolulu, $18 \mathrm{Au}$ gust 1987, and at the Annual Joint Scientific Sessions of the American Federation for Clinical Research, American Society for Clinical Investigation and American Association of Physicians at Washington, DC, 30 April 1988.

Address reprint requests to Dr. Liang, Cardiology Research Laboratories, Cardiology Unit, Box 679, University of Rochester Medical Center, Rochester, NY 14642.

Received for publication 15 June 1988 and in revised form 1 May 1989.

J. Clin. Invest.

(c) The American Society for Clinical Investigation, Inc.

$0021-9738 / 89 / 10 / 1267 / 09 \$ 2.00$

Volume 84, October 1989, 1267-1275
$6,7)$, and a reduced number of myocardial beta-adrenergic receptors $(6,7)$. Since the number of cell surface beta-receptors decreases in a variety of in vitro cell preparations after beta-agonist exposure (8-10), the reduction in myocardial beta-receptor number in heart failure has been thought to be caused by agonist-induced downregulation, known also as homologous desensitization (8). However, chronic intravenous administration of NE in intact dogs has failed to decrease myocardial beta-receptor number $(11,12)$. Nevertheless, these findings do not refute the role of homologous desensitization since plasma NE concentration is not necessarily similar to the neurotransmitter concentration at the synaptic cleft. The synaptic NE surrounding beta-receptors is influenced not only by the circulating NE, but also by the amount of neuronally released NE, local metabolizing enzymes, and adequacy of NE uptake activity at the presynaptic nerve endings. Because neuronal reuptake is the major mechanism in terminating the pharmacological action of catecholamines, we speculate that unless the NE uptake mechanism is defective, NE infusion may not increase synaptic NE concentration sufficiently high to cause beta-receptor downregulation. Indeed, unlike the response in intact normal dogs, NE infusion causes a decrease in myocardial beta-receptor density in dogs after cardiac denervation (13), a condition that has been shown to reduce NE uptake (14).

Increasing evidence has accumulated that myocardial NE uptake activity is depressed in failing myocardium (15-17). In this study we sought to determine whether the reduction of myocardial beta-adrenoceptor density in heart failure is associated with alterations in NE uptake activity. Studies were performed in dogs with experimental right heart failure $(\mathrm{RHF})^{1}$ produced by tricuspid avulsion and progressive pulmonary artery constriction. As in patients with heart failure caused by primary pulmonary hypertension (18), such animals exhibit a chamber-specific reduction of myocardial betaadrenoceptors in the failing right ventricle, while the left ventricular beta-receptor number remains normal (19). Since both the right and left ventricles are exposed to the same levels of circulating NE, this animal preparation offers a unique opportunity to determine whether a local factor in the right ventricle accounts for the chamber-specific beta-receptor downregulation. We measured beta-adrenoceptor density, NE uptake activity, and NE uptake-1 carrier density in both the right and left ventricles. The left kidney was studied as an extracardiac reference. Results of the study indicate that the beta-adrenoceptor downregulation in RHF is associated with a chamberand organ-specific reduction in NE uptake-1 carrier density and decrease in NE uptake activity.

1. Abbreviations used in this paper: $B_{\max }$, maximum binding site; DHA, dihydroalprenolol; RHF, right heart failure. 


\section{Methods}

Surgical preparation. RHF was produced in $\mathbf{3 0}$ adult mongrel dogs weighing 19-32 kg using a modified technique $(19,20)$ of Barger and co-workers (21). Animals were anesthetized with sodium pentobarbital $(25 \mathrm{mg} / \mathrm{kg}$ i.v.) and ventilated with room air using a respirator (Harvard Apparatus Co., Inc., S. Natick, MA). A sterile right thoracotomy was performed through the fifth intercostal space. After the pericardial sac was opened to expose the heart, a purse string suture was placed at the base of the right atrium. With venous return transiently occluded, an incision was made within the purse string, and an index finger inserted into the right ventricle to rupture the chordae tendineae of the anterior tricuspid leaflet. A heparin-filled Tygon catheter $(1.02 \mathrm{~mm}$ internal diameter; Norton Co., Plastics and Synthetics Division, Akron, $\mathrm{OH}$ ) was then inserted into the right atrium, and the atrium was closed by tightening the purse string suture. 2 wk later, a left thoracotomy was performed via the fifth intercostal space. A Silastic Jones hydraulic balloon occluder (R. E. Jones, Silver Springs, MD) was placed around the main pulmonary artery. A micromanometer (Konigsberg Instruments, Inc., Pasadena, CA) was inserted into the left ventricular cavity through a stab wound at the apex. Tygon catheters were inserted into the aorta, the main pulmonary artery distal to the occluder, and the left atrium. The catheters were exteriorized to the back of the neck and the chest was closed. The animals received antibiotics for 1 wk after each surgery.

Beginning 2 wk after the second surgery, the pulmonary artery occluder was progressively inflated, once or twice a week, to increase right atrial pressure to $13-17 \mathrm{mmHg}$. A steady elevation in right atrial pressure and prominent ascites were attained in $2-4 \mathrm{wk}$. Animals were studied 5-19 wk after the second surgery.

Sham operation was performed in 23 dogs. It differed from the aforementioned two-staged procedure only in that neither tricuspid avulsion nor pulmonary artery constriction was performed.

The study was approved by the University of Rochester Committee on Animal Resources, and conformed to the guiding principles approved by the Council of the American Physiological Society and the National Institutes of Health Guide on the humane care and use of laboratory animals.

Systemic hemodynamic measurements. By the time of study, animals had been acclimatized to the laboratory environment and trained to lie quietly on an examination table. The chronically implanted Tygon catheters were connected to pressure transducers (P23Db; Statham Instruments, Inc., Oxnard, CA) and a multichannel Brush model 480 recorder (Gould, Inc., Instrument Systems Division, Cleveland, $\mathrm{OH}$ ), for measuring right atrial, left atrial, and aortic pressures. The Konigsberg micromanometer was connected to the Brush recorder for measuring the first derivative of left ventricular pressure $(\mathrm{d} P / \mathrm{d} t)$. The ratio of left ventricular $\mathrm{d} P / \mathrm{d} t$ at a developed pressure of 50 mmHg to the developed pressure $(\mathrm{d} P / \mathrm{d} t / P)$, which has been shown to be relatively independent of the ventricular afterload (22), was used as an index of left ventricular contractility. Right ventricular pressure and its peak rate of pressure rise were measured by a catheter (Millar Instruments, Inc., Houston, TX) inserted via an external jugular vein under local anesthesia. Heart rate was obtained from the electrocardiogram. Cardiac output was measured by injecting indocyanine green (Cardio-Green; Hynson, Westcott \& Dunning, Inc., Baltimore, MD) into the pulmonary artery and sampling the arterial blood for dye concentrations using a cardiac output system (model 140; Gilford Instrument Laboratories, Inc., Oberlin, $\mathrm{OH}$ ). Resting systemic hemodynamic measurements were obtained in triplicate at least $1 \mathrm{~h}$ after insertion of the Millar catheter. In addition, aortic blood was sampled for plasma catecholamine determinations (see below).

Animals were sacrificed by a lethal dose of sodium pentobarbital. Tissue blocks were removed from the right and left ventricular free walls $3 \mathrm{~cm}$ below the atrioventricular groove and from the renal cortex near the lateral margin of the left kidney. Fresh tissue samples were used for measuring NE uptake activity, while other specimens were stored immediately in liquid nitrogen for subsequent measurements of tissue norepinephrine, beta-receptor number, and NE uptake-1 carrier density.

Analysis of plasma and myocardial catecholamine concentrations. Plasma and tissue catecholamines were determined radioenzymatically (23), using the commercially available Cat-A-Kit reagents (Amersham Corp., Arlington Heights, IL). Tissue samples were minced and suspended in a $0.4 \mathrm{~N}$ perchloric acid with $5 \mathrm{mM}$ reduced glutathione solution ( $\mathrm{pH} 7.4$ ), homogenized with a Polytron PCU-2 homogenizer (8-s bursts $\times 3$ at setting 8; Brinkmann Instruments, Inc., Westbury, NY), and centrifuged at $500 \mathrm{~g}$. The supernatant was taken for catecholamine assay.

Measurement of $\left[{ }^{3} H\right] N E$ uptake activity. The procedure for $\left[{ }^{3} \mathrm{H}\right] \mathrm{NE}$ uptake studies was similar to that previously described by Sharma and Banerjee (24). Tissue slices, $0.5 \mathrm{~mm}$ thick and weighing $\sim 30 \mathrm{mg}$, were prepared from blocks of fresh myocardium or renal cortex using a Stadie-Riggs tissue microtome (Thomas Scientific, Swedesboro, NJ). Tissue was kept in an oxygenated modified Krebs solution. The composition of the modified Krebs solution was (in $\mathrm{mM}$ ): $\mathrm{NaCl} 118, \mathrm{KCl} 4.7, \mathrm{CaCl}_{2} 2.5, \mathrm{MgCl}_{2} 0.54, \mathrm{NaHCO}_{3} 25$, $\mathrm{NaH}_{2} \mathrm{PO}_{4} 1$, and dextrose 11 . Also included in the Krebs solution were EDTA $20 \mathrm{mg} / \mathrm{liter}$, ascorbic acid $200 \mathrm{mg} / \mathrm{liter}$, and nialamide $3.5 \mathrm{mg} /$ liter.

NE uptake activity was measured in triplicate by incubating tissue slices at $37^{\circ} \mathrm{C}$ for $15 \mathrm{~min}$ in three baths of modified Krebs solution containing $12.5,25$, and $50 \mathrm{nM} \mathrm{D,L}-\left[7-{ }^{3} \mathrm{H}(\mathrm{N})\right] \mathrm{NE}$ hydrochloride $(12.8$ $\mathrm{Ci} / \mathrm{mmol}$; New England Nuclear, Boston, MA). Nonspecific accumulation of radioactivity (blanks) was determined by parallel incubation of triplicate tissue slices at $4^{\circ} \mathrm{C}$. After incubation, tissue slices were rinsed three times with an ice-cold modified Krebs solution, blotted on filter paper, and placed in a test tube containing ice-cold $4 \%$ TCA. After $21 \mathrm{~h}$ of acid extraction at $4^{\circ} \mathrm{C}$, an aliquot was taken for counting ${ }^{3} \mathrm{H}$-radioactivity by liquid scintillation spectrometry (Packard Instrument Co., Inc., Downers Grove, IL).

Tyramine-induced release of NE from heart slices. Because tissue accumulation of $\left[{ }^{3} \mathrm{H}\right] \mathrm{NE}$ is influenced not only by NE uptake activity but also by the rate of NE release, studies were also performed to determine the rate of release of $\left[{ }^{3} \mathrm{H}\right] \mathrm{NE}$ from heart slices with and without tyramine. Tissue slices were preincubated in duplicate for $\mathbf{3 0}$ min at $37^{\circ} \mathrm{C}$ in a fresh oxygenated modified Krebs solution which contained $50 \mathrm{nM}\left[{ }^{3} \mathrm{H}\right] \mathrm{NE}$ and $100 \mu \mathrm{M}$ pargyline, a monoamine oxidase inhibitor. The tissue slice was then rinsed three times with a $\left[{ }^{3} \mathrm{H}\right] \mathrm{NE}$-free Krebs solution, blotted on filter paper, and placed in $4 \mathrm{ml}$ of a modified Krebs solution containing $100 \mu \mathrm{M}$ pargyline. $10 \mathrm{~min}$ later, with the tissue freely suspended, $50 \mu \mathrm{l}$ of a tyramine solution was added into the incubation medium to achieve a final concentration of $100 \mu \mathrm{M}$. Beginning with the addition of tyramine, $50-\mu 1$ aliquots of the incubation medium were taken for counting ${ }^{3} \mathrm{H}$-radioactivity at 5-min intervals for $25 \mathrm{~min}$. Finally, $200 \mu \mathrm{l}$ of a $75 \%$ TCA solution was added to extract tissue NE; an aliquot of the incubation solution was taken for calculating the total amount of $\left[{ }^{3} \mathrm{H}\right] \mathrm{NE}$ present in the tissue. Spontaneous release of ${ }^{3} \mathrm{H}$ was determined by parallel incubation of two other tissue slices, using deionized water instead of tyramine. The difference in ${ }^{3} \mathrm{H}$ release between the tissue slices with and without tyramine was taken to indicate the tyramine-induced release of NE.

Preparation of the ventricular and renal particulate fractions. A block of ventricular free wall was trimmed free of fat, large vessels, and $1 \mathrm{~mm}$ of its inner and outer surfaces. It was minced and homogenized in an ice-cold $50 \mathrm{mM}$ Tris $\mathrm{HCl}$ buffer (buffer $\mathrm{I}, \mathrm{pH} 7.7$ at $25^{\circ} \mathrm{C}$ ), using a PCU-2 homogenizer (8-s burst $\times 5$ at setting 8 ). The homogenate was diluted with additional Tris buffer and centrifuged at $500 \mathrm{~g}$ for $15 \mathrm{~min}$ at $4^{\circ} \mathrm{C}$. The supernatant were spun again at $40,000 \mathrm{~g}$ for $15 \mathrm{~min}$ at $4^{\circ} \mathrm{C}$. The resulting pellets were resuspended and washed with a second buffer solution containing $50 \mathrm{mM}$ Tris $\mathrm{HCl}, 120 \mathrm{mM} \mathrm{NaCl}, 5 \mathrm{mM}$ $\mathrm{KCl}$, pH 7.4 at $25^{\circ} \mathrm{C}$ (buffer II), and filtered through a 53- $\mu \mathrm{m}$ nylon mesh. This filtrate containing crude membrane fractions was then diluted with buffer II to yield a protein concentration of $\sim 0.35 \mathrm{mg} / \mathrm{ml}$ for radioligand binding studies. Protein concentration was determined in triplicate by the method of Lowry et al. (25), using bovine serum albumin as a standard. 
The renal cortex was trimmed free of capsular membranes and large vessels, minced with scissors, and homogenized in ice-cold buffer I using a Polytron homogenizer (8-s burst $\times 3$ at setting 6 ). The homogenate was centrifuged at $500 \mathrm{~g}$ for $15 \mathrm{~min}$ at $4^{\circ} \mathrm{C}$. The supernatant was spun again at $40,000 \mathrm{~g}$ for $15 \mathrm{~min}$ at $4^{\circ} \mathrm{C}$. The resultant pellet was resuspended in buffer $I$ and washed. The final pellet was resuspended in buffer I, filtered through a $53-\mu \mathrm{m}$ nylon mesh, and used immediately for radioligand binding studies.

Radioligand binding studies. NE uptake-1 carrier density was quantitated by the $\left[{ }^{3} \mathrm{H}\right]$ mazindol binding assay described by Javitch et al. (26), with minor modifications. Approximately $70 \mu \mathrm{g}$ of membrane protein was incubated in triplicate at $37^{\circ} \mathrm{C}$ for $20 \mathrm{~min}$ with varying concentrations (3-45 $\mathrm{nM})$ of $\left[{ }^{3} \mathrm{H}\right]$ mazindol $(16.8 \mathrm{Ci} / \mathrm{mmol}$; New England Nuclear) in the presence of either $0.3 \mu \mathrm{M}$ desipramine (for estimation of nonspecific binding) or vehicle (total binding). Specific binding, defined as the difference between the total and nonspecific binding, accounted for $60-70 \%$ of the total binding at $5 \mathrm{nM}$ of $\left[{ }^{3} \mathrm{H}\right]-$ mazindol.

Beta-adrenoceptor density was quantitated using $\left[{ }^{3} \mathrm{H}\right]$ dihydroalprenolol (DHA, $95 \mathrm{Ci} / \mathrm{mmol}$; New England Nuclear) as the radioligand (27). Approximately $70 \mu \mathrm{g}$ of membrane protein was incubated with appropriate concentrations of $\left[{ }^{3} \mathrm{H}\right] \mathrm{DHA}(0.5-12 \mathrm{nM})$, in the presence of either $1 \mu \mathrm{M} \mathrm{L}$-alprenolol or vehicle, at $37^{\circ} \mathrm{C}$ for $20 \mathrm{~min}$ in a final volume of $0.25 \mathrm{ml}$. The reaction was terminated by the addition of $5 \mathrm{ml}$ ice-cold buffer II and filtered immediately through Whatman GF/C filters on a Brandel cell harvester (Biomedical Research and Development Laboratories, Inc., Gaithersberg, MD), followed by three additional washes with the same buffer. Specific binding was defined as the difference between binding of the radioligand in the absence and presence of $\mathrm{L}$-alprenolol.

The number of maximum binding sites $\left(B_{\max }\right)$ and the dissociation constant $\left(K_{\mathrm{d}}\right)$ for both radioligand binding studies were calculated using Scatchard analysis (28) with the EBDA software program developed by McPherson (29) (Elsevier Science Publisher, Cambridge, UK).

Data analysis. Results are expressed as mean \pm SE. The statistical significance of differences between the RHF and sham-operated dogs was determined using analysis of variance for determining equality of variance and $t$ test for unpaired data. The degree of relatedness between two variables was determined using Pearson's correlation coefficient and coefficient of determination. The data were analyzed using RS/1 data analysis system (BBN Software Products Corp., Cambridge, MA). Values were considered statistically significant if $P<0.05$.

\section{Results}

Resting systemic hemodynamics. Animals with RHF showed prominent ascites and a heavier body weight than sham-operated controls (Table I). The RHF animals also had a signifi-

Table I. Hemodynamic Characteristics

\begin{tabular}{lcc}
\hline & Sham (23) & RHF (30) \\
\hline Body weight $(\mathrm{kg})$ & $23.6 \pm 0.6$ & $25.7 \pm 0.6^{*}$ \\
Right atrial pressure $(\mathrm{mmHg})$ & $3.6 \pm 0.2$ & $13.6 \pm 0.6^{\ddagger}$ \\
Heart rate $(\mathrm{bpm})$ & $97 \pm 3$ & $147 \pm 3^{\ddagger}$ \\
Mean aortic pressure $(\mathrm{mmHg})$ & $108 \pm 2$ & $95 \pm 2^{\ddagger}$ \\
Cardiac output $(\mathrm{liters} / \mathrm{min})$ & $3.67 \pm 0.11$ & $2.70 \pm 0.08^{\ddagger}$ \\
Left atrial pressure $(\mathrm{mmHg})$ & $6.5 \pm 0.3$ & $3.8 \pm 0.3^{\ddagger}$ \\
$\mathrm{RV} d P / d t(\mathrm{mmHg} / \mathrm{s})$ & $666 \pm 22$ & $517 \pm 25^{\S}$ \\
$\mathrm{LV} d P / d t(\mathrm{mmH} / \mathrm{s})$ & $3084 \pm 99$ & $2196 \pm 54^{\ddagger}$ \\
$\mathrm{LV} d P / d t / P\left(\mathrm{~s}^{-1}\right)$ & $48.2 \pm 0.8$ & $38.2 \pm 0.7^{\ddagger}$ \\
\hline
\end{tabular}

Values are mean $\pm \mathrm{SE}$. The number of experiments is given in parentheses. RV, right ventricular. $L V$, left ventricular. ${ }^{*} P=0.016,{ }^{\ddagger} P$ $<0.0001$, and ${ }^{\S} P<0.001$ compared with the sham group.
Table II. Plasma and Tissue Catecholamine Contents

\begin{tabular}{lcc}
\hline & Sham & RHF \\
\hline Plasma NE $(n g / m l)$ & $0.17 \pm 0.01(18)$ & $0.45 \pm 0.06^{*}(30)$ \\
Plasma epinephrine $(n g / m l)$ & $0.11 \pm 0.01(18)$ & $0.17 \pm 0.02^{\ddagger}(30)$ \\
Tissue NE $(\mu g / g)$ & & \\
$\quad$ Right ventricle & $1.22 \pm 0.08(20)$ & $0.07 \pm 0.02^{\S}(28)$ \\
Left ventricle & $1.45 \pm 0.11(20)$ & $0.29 \pm 0.05^{\S}(28)$ \\
Renal cortex & $0.72 \pm 0.11(9)$ & $0.56 \pm 0.06(14)$
\end{tabular}

Values are mean $\pm \mathrm{SE}$. The number of experiments is given in parentheses. ${ }^{*} P<0.001,{ }^{\ddagger} P=0.003$, and ${ }^{\S} P<0.0001$ compared with the sham group.

cantly greater right atrial pressure, faster heart rate, lower mean aortic pressure, lower cardiac output, and reduced left atrial pressure, right ventricular $\mathrm{d} P / \mathrm{d} t$ and left ventricular $\mathrm{d} P / \mathrm{d} t$ and $\mathrm{d} P / \mathrm{d} t / P$. In addition, right ventricular free wall weight was greater in the RHF group $(50.3 \pm 1.9 \mathrm{~g})$ compared with the sham group $(39.9 \pm 1.3 \mathrm{~g}, t=4.56$, d.f. $=51, P$ $<0.001$ ).

Plasma and tissue catecholamine levels. Arterial plasma $\mathrm{NE}$ and epinephrine concentrations were elevated in RHF (Table II). In contrast, myocardial NE content was markedly reduced. Furthermore, although NE was reduced in both ventricles, NE depletion was significantly greater in the failing right ventricle than in the left ventricle. In contrast, renal NE content did not differ between the RHF and sham-operated dogs.

Beta-adrenoceptor density. Table III shows that compared with sham-operated dogs, RHF dogs had a $26 \%$ decrease in right ventricular beta-adrenoceptor density. In contrast, neither left ventricular nor renal beta-adrenoceptor density differed between the two groups. Nor did the two groups differ in their dissociation constants of the beta-adrenoceptors in the right ventricle and kidneys. However, the dissociation constant of the left ventricular beta-adrenoceptor was slightly greater in RHF dogs than sham-operated dogs.

$N E$ uptake activity and binding sites. Specific ${ }^{3} \mathrm{H}$ uptake activity was measured to approximate NE uptake activity. Fig. 1 shows that the amount of ${ }^{3} \mathrm{H}$ taken up by the myocardial tissue was in direct proportion to the concentrations of $\left[{ }^{3} \mathrm{H}\right] \mathrm{NE}$ present in the incubation medium. Compared with shamoperated dogs, RHF dogs exhibited an attenuated NE uptake

Table III. Binding Characteristics of $\left[{ }^{3} \mathrm{H}\right] \mathrm{DHA}$ to Myocardial and Renal Crude Membrane Preparations

\begin{tabular}{lcc}
\hline & Sham & RHF \\
\hline$B_{\max }(f$ mol/mg protein $)$ & & \\
$\quad$ Right ventricle & $107 \pm 5(20)$ & $79 \pm 6^{*}(26)$ \\
Left ventricle & $116 \pm 6(21)$ & $108 \pm 5(27)$ \\
Renal cortex & $51 \pm 6(6)$ & $55 \pm 3(6)$ \\
$K_{\mathrm{d}}(n M)$ & & \\
Right ventricle & $2.4 \pm 0.2$ & $2.7 \pm 0.2$ \\
Left ventricle & $2.3 \pm 0.1$ & $3.0 \pm 0.2^{*}$ \\
Renal cortex & $2.3 \pm 0.5$ & $1.9 \pm 0.4$ \\
& & \\
\hline
\end{tabular}

Values are mean $\pm \mathrm{SE}$. The number of experiments is given in parentheses. ${ }^{*} P<0.001$ compared with the sham group. 


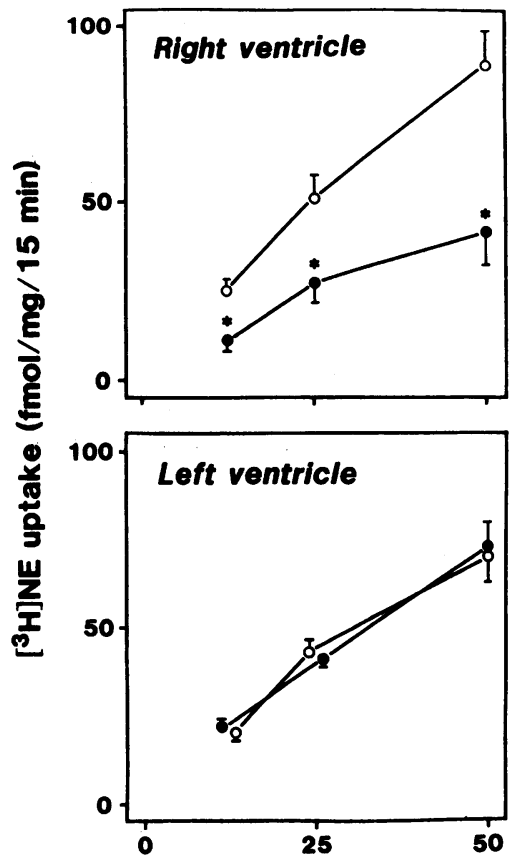

[ ${ }^{3}$ H]NE concentration (nM)
Figure 1. Specific ${ }^{3} \mathrm{H}$ uptake activity (representing tissue $\left[{ }^{3} \mathrm{H}\right] \mathrm{NE}$ uptake), at three different concentrations of $\left[{ }^{3} \mathrm{H}\right] \mathrm{NE}$, using fresh tissue slices taken from the right and left ventricular free walls of sham-operated (open circles) and RHF (closed circles) dogs. Bars indicate SE. Asterisks denote values that differ significantly from the sham group at $P$ $<0.05$. Nonspecific ${ }^{3} \mathrm{H}$ uptake did not differ significantly between the two groups. The values of nonspecific ${ }^{3} \mathrm{H}$ uptake (fmol/mg per 15 min, mean \pm SE) at each of the three incubation concentrations were: left ventricles of the sham animals $(5.4 \pm 0.6$, $10.6 \pm 0.9,19.3 \pm 1.5)$; left ventricles of the RHF animals $(4.9 \pm 0.3$, $11.2 \pm 0.9,20.6 \pm 1.2)$; right ventricles of the sham animals $(5.5 \pm 0.5$, $10.1 \pm 0.8,18.4 \pm 1.3)$; right ventricles of the RHF animals $(5.8 \pm 0.4$, $10.0 \pm 0.5,19.5 \pm 1.3)$.

activity in the right ventricle for the three concentrations of $\left[{ }^{3} \mathrm{H}\right] \mathrm{NE}$ tested. However, the two groups did not differ in left ventricular NE uptake. Table IV summarizes the NE uptake activity in the right and left ventricles and the renal cortex, at the highest $\left[{ }^{3} \mathrm{H}\right] \mathrm{NE}$ concentration tested. The table shows that NE uptake was reduced in the right ventricle of the RHF dogs, but neither left ventricular nor renal NE uptake differed significantly between the RHF and sham-operated dogs.

A representative Scatchard plot of specific binding of $\left[{ }^{3} \mathrm{H}\right]-$ mazindol is shown in Fig. 2. Specific $\left[{ }^{3} \mathrm{H}\right]$ mazindol binding to myocardial membrane was saturable and reversible. The single component, linear Scatchard relationship indicates a single class of $\left[{ }^{3} \mathrm{H}\right]$ mazindol binding sites (inset). A near-unity Hill coefficient in the Hill plot indicates that there was no coopera-

Table IV. Uptake of $\left[{ }^{3} \mathrm{H}\right] \mathrm{NE}$ by Fresh Tissue Slices Obtained from Sham-operated Dogs and Dogs with RHF

\begin{tabular}{lll}
\hline & \multicolumn{2}{c}{ Specific ${ }^{3} \mathrm{H}$ uptake } \\
\cline { 2 - 3 } & \multicolumn{1}{c}{ Sham } & \multicolumn{1}{c}{ RHF } \\
\hline & \multicolumn{2}{c}{$f m o l / m g / 15 ~ m i n$} \\
Right ventricle & $86.5 \pm 5.2(23)$ & $42.1 \pm 5.0^{*}(30)$ \\
Left ventricle & $73.3 \pm 4.7(23)$ & $79.1 \pm 4.2(29)$ \\
Renal cortex & $50.8 \pm 3.2(6)$ & $47.5 \pm 4.6(7)$
\end{tabular}

Values (mean $\pm \mathrm{SE}$ ) are specific ${ }^{3} \mathrm{H}$ uptake $\left({ }^{3} \mathrm{H}\right.$ uptake at $37^{\circ} \mathrm{C}$ minus ${ }^{3} \mathrm{H}$ uptake at $4^{\circ} \mathrm{C}$ ) by the tissue slices over $15 \mathrm{~min}$ in an incubation medium containing $50 \mathrm{nM}\left[{ }^{3} \mathrm{H}\right] \mathrm{NE}$. The number of experiments is given in parentheses. ${ }^{*} P<0.0001$ compared with the sham group.

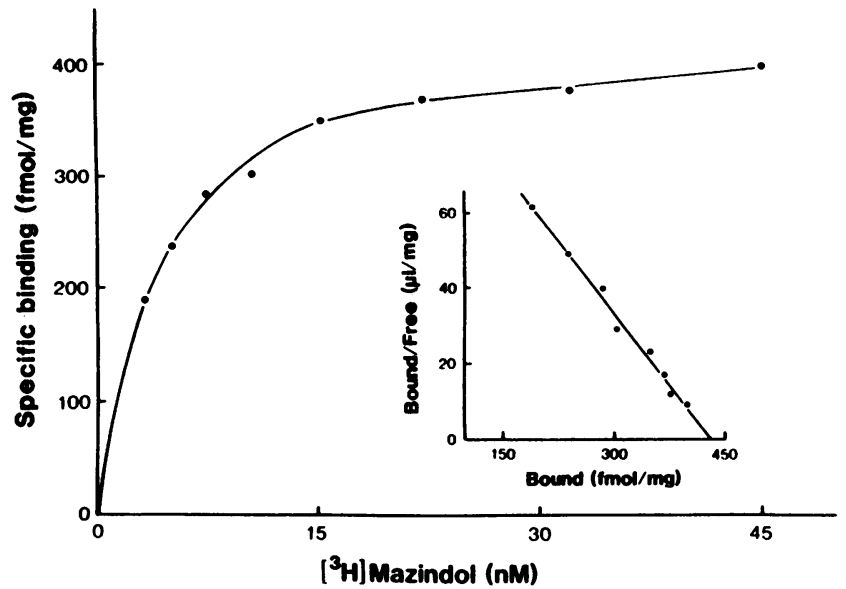

Figure 2. A characteristic $\left[{ }^{3} \mathrm{H}\right]$ mazindol radioligand binding study for measuring NE uptake-1 carrier site density. A Scatchard plot is shown in inset.

tivity among binding of the $\left[{ }^{3} \mathrm{H}\right]$ mazindol molecules to the cardiac membrane. This property of mazindol binding was not altered by RHF.

Results of $\left[{ }^{3} \mathrm{H}\right]$ mazindol binding experiments are summarized in Table V. RHF animals showed a smaller number of maximum mazindol binding sites $\left(B_{\max }\right)$ in the right ventricle than sham-operated dogs, but mazindol $B_{\max }$ did not differ in the left ventricle between the two groups. Neither was the dissociation constant for either ventricle affected by RHF.

Tyramine-induced NE release. Fig. 3 shows the cumulative relative release of ${ }^{3} \mathrm{H}$ over a 25 -min period from the right and left ventricular muscle slices in the presence and absence of tyramine. Neither the spontaneous release nor tyramine-induced release of ${ }^{3} \mathrm{H}$ differed significantly in the right or left ventricle between the RHF and sham animals.

Correlation of beta-adrenoceptor density with $N E$ uptake and plasma NE. Table VI lists correlation coefficients and coefficients of determination for correlations between betaadrenoceptor density and biochemical measurements in the failing right ventricle. Beta-receptor density correlated significantly with both NE uptake activity (Fig. 4) and NE uptake-1 carrier density. NE uptake activity also correlated significantly with NE uptake-1 carrier density (Fig. 5). In addition, there was an inverse correlation between beta-receptor density and $\mathrm{NE}$ content of the failing hearts. In contrast, right ventricular

Table V. Binding Characteristics of $\left[{ }^{3} \mathrm{H}\right] \mathrm{Mazindol}$ to Myocardial Crude Membrane Preparations

\begin{tabular}{lll}
\hline & Sham (16) & RHF (20) \\
\hline$B_{\max }($ fmol/mg protein $)$ & & \\
$\quad$ Right ventricle & $477 \pm 41$ & $203 \pm 22^{*}$ \\
$\quad$ Left ventricle & $601 \pm 46$ & $521 \pm 37$ \\
$K_{\mathrm{d}}(n M)$ & & \\
Right ventricle & $12.4 \pm 1.7$ & $11.3 \pm 1.5$ \\
Left ventricle & $11.8 \pm 1.9$ & $10.5 \pm 1.1$
\end{tabular}

Values are mean $\pm \mathrm{SE}$. The number of experiments is given in parentheses. ${ }^{*} P<0.0001$ compared with the sham group. 


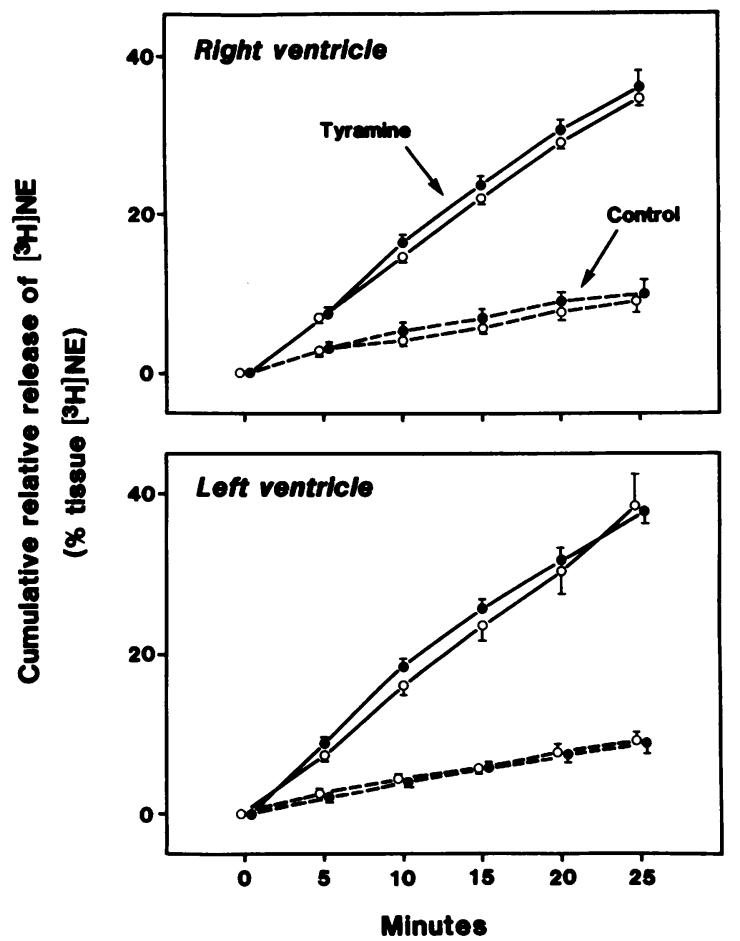

Figure 3. Cumulative relative release of ${ }^{3} \mathrm{H}$ after addition of either tyramine or deionized water (control) from the right and left ventricular slices of the sham-operated (open circles, $n=5$ ) and RHF dogs (closed circles, $n=6$ ). The tissue slices were preincubated in a $\left[{ }^{3} \mathrm{H}\right] \mathrm{NE}$ containing solution. Bars indicate SE.

beta-receptor density correlated with neither plasma NE concentration nor the duration of heart failure in the RHF dogs. Because the precise timing of onset of RHF could not be defined, the duration of RHF was approximated by the interval between the second surgery and sacrifice (35-124 d; 66 $44 \mathrm{~d})$.

\section{Discussion}

As we have shown previously in dogs with RHF (19), our present study confirms that beta-adrenoceptor number is re-

Table VI. Correlation Coefficients and Coefficients of Determination of Biochemical and NE Changes in the Failing Right Heart

\begin{tabular}{lcc}
\hline \multicolumn{1}{c}{ Variables } & $\begin{array}{c}\text { Correlation } \\
\text { coefficient } \\
(r)\end{array}$ & $\begin{array}{c}\text { Coefficient of } \\
\text { determination } \\
\left(r^{2}\right)\end{array}$ \\
\hline $\begin{array}{l}\text { Beta-receptor density vs. NE uptake activity } \\
\text { Beta-receptor density vs. NE uptake site }\end{array}$ & $0.818^{*}$ & 0.668 \\
$\quad$ number & $0.728^{*}$ & 0.530 \\
$\begin{array}{l}\text { NE uptake activity vs. NE uptake site } \\
\text { number }\end{array}$ & $0.881^{*}$ & 0.775 \\
Beta-receptor density vs. tissue [NE] & $0.441^{\ddagger}$ & 0.195 \\
Beta-receptor density vs. RHF duration & -0.073 & 0.005 \\
Beta-receptor density vs. arterial [NE] & 0.080 & 0.006 \\
\hline
\end{tabular}

* Values that are statistically significant at $P<0.001 .{ }^{\ddagger}$ The value that is statistically significant at $P<0.05$.

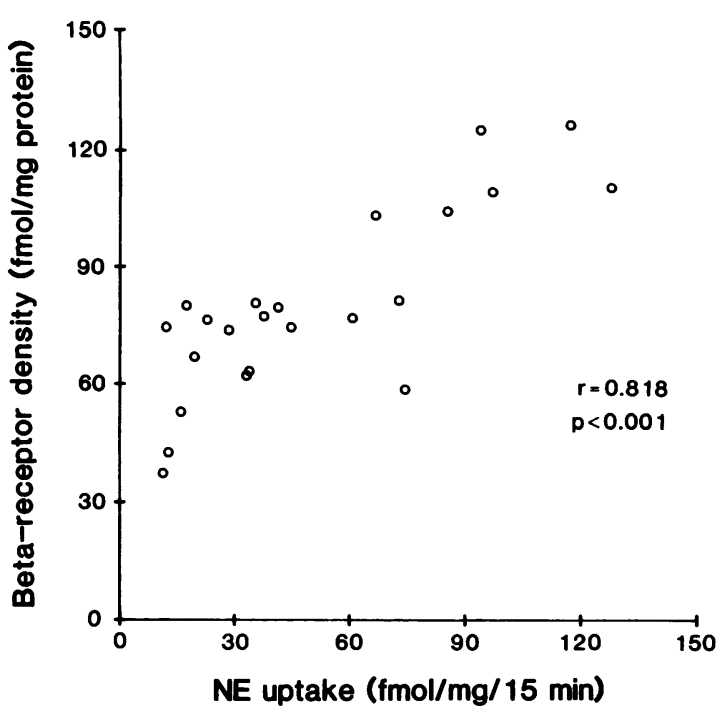

Figure 4. Correlation between beta-receptor density and NE uptake activity (specific ${ }^{3} \mathrm{H}$ uptake) of the right ventricles of RHF dogs.

duced in the failing right ventricle, but is relatively unchanged in the left ventricle. Similar chamber-specific changes have been reported in patients with right ventricular failure secondary to primary pulmonary hypertension (18). The RHF dogs have been extensively studied; they exhibit an increase in plasma catecholamines, a decrease in myocardial NE stores, a reduced responsiveness to beta-receptor agonists (19), and other neurohormonal and reflex changes (30-34) that occur in patients with congestive heart failure.

Specific ${ }^{3} \mathrm{H}$ uptake activity, defined as the difference in radioactivity between tissue slices incubated in a $\left[{ }^{3} \mathrm{H}\right] \mathrm{NE}$-containing solution at $37^{\circ} \mathrm{C}$ (total ${ }^{3} \mathrm{H}$ uptake) and those at $4^{\circ} \mathrm{C}$ (nonspecific ${ }^{3} \mathrm{H}$ uptake), was taken to approximate NE uptake activity in the present study. Ascorbic acid and nialamide were

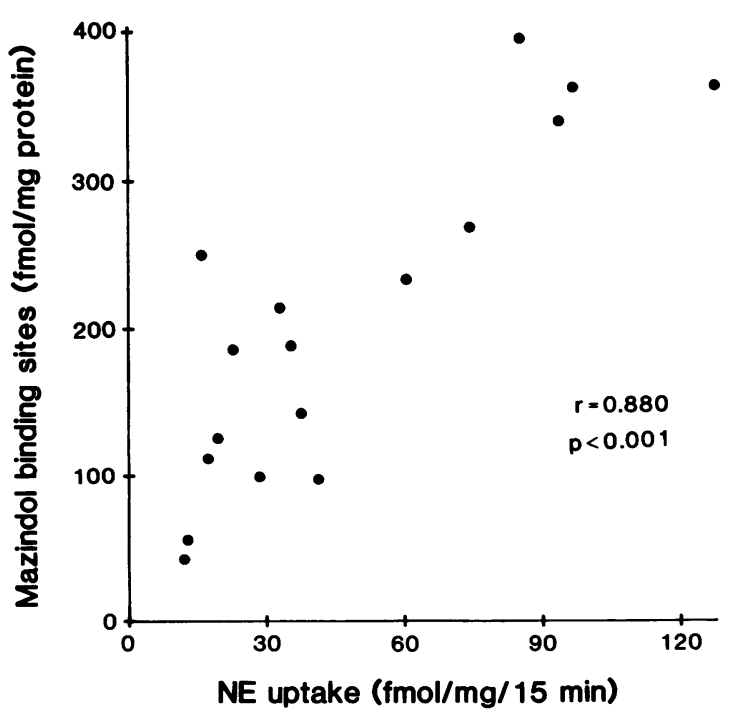

Figure 5. Correlation between mazindol binding sites (NE uptake carrier site density) and NE uptake activity (specific ${ }^{3} \mathrm{H}$ uptake) of the right ventricles of RHF dogs. 
added to our incubation medium to retard spontaneous oxidation of NE and the activity of monoamine oxidase. Sharma and Banerjee (24) have shown that under the same experimental conditions, $>90 \%$ of the tissue radioactivity derives from the unmetabolized catecholamine. These findings are consistent with the observation that NE metabolites account for $<4 \%$ of the total ${ }^{3} \mathrm{H}$ recovered in a similar incubation medium (35). Furthermore, as shown by Sharma and Banerjee (24), we have confirmed that the temperature-dependent accumulation of ${ }^{3} \mathrm{H}$ in heart muscle can be either abolished or markedly reduced by ouabain, a $\mathrm{Na}^{+}-\mathrm{K}^{+}$ATPase inhibitor, and desipramine, a NE uptake-1 carrier inhibitor (unpublished data). On the other hand, propranolol, phentolamine, and prazocin exert no effects on specific ${ }^{3} \mathrm{H}$ uptake. These findings indicate that the specific ${ }^{3} \mathrm{H}$ uptake is an active, energy-dependent process that requires normally functioning NE uptake-1 carrier sites, and that binding of $\left[{ }^{3} \mathrm{H}\right] \mathrm{NE}$ to alpha- and beta-adrenoceptors contributes negligibly to the total tissue ${ }^{3} \mathrm{H}$ radioactivity.

Our present study indicates no difference in either spontaneous or tyramine-induced release of NE between the normal and failing right ventricles. Similarly, using an in vivo labeling technique, Spann et al. (36) found the absolute levels of specific activity and the rates of disappearance were identical in the left ventricles of normal guinea pigs and those with heart failure produced by aortic constriction. The relative net turnover rates of $\mathrm{NE}$ were the same in the normal and failing hearts. The investigators concluded that NE release was not increased in heart failure. These results suggest that the primary defect of NE metabolism of the failing ventricle lies in the NE uptake mechanism.

Compared with sham animals, RHF dogs showed an average of $51 \%$ reduction of NE uptake activity and a $26 \%$ decrease in beta-receptor number in the failing right ventricle. Like that of beta-receptor number, this change in NE uptake was not only organ specific but also chamber specific, because neither the left ventricle nor the kidney showed abnormal NE uptake activity. Our $\left[{ }^{3} \mathrm{H}\right]$ mazindol binding data further indicate that the diminished NE uptake activity was associated, at least in part, with a reduction in the number of NE uptake-1 carrier.

Our results further show that myocardial beta-receptor number correlated significantly with NE uptake activity and NE uptake- 1 carrier density in the failing heart. Although the associations do not establish a cause and effect relationship, the coefficient of determination indicates that NE uptake activity contributed statistically to $66.8 \%$ of the changes in total beta-receptor number in the study. Recent evidence indicates that the decrease in beta-receptor number in the failing human heart is caused predominantly by a selective downregulation of beta-1 receptors (37). Unlike beta-1 receptors, myocardial beta- 2 receptors do not change significantly in heart failure. If the human findings could be extrapolated to the experimental animals, the reduction of total beta-receptor number in our animals probably also was due to a selective decrease in beta- 1 receptors. The percent decrease of beta- 1 receptor density would then be expected to be greater than that of total beta-receptor density, and the beta- 1 receptor number might be more closely correlated with NE uptake activity than was the total beta-receptor number. However, because we employed the nonselective antagonist alprenolol, our present study does not allow us to discriminate between the beta-receptor subtypes. Further investigations might be needed to establish the quan- titative correlation between NE uptake activity and beta-1 receptor number.

The mechanism by which NE uptake- 1 carrier density was reduced is not known. However, it cannot be explained by an increase in muscle mass alone, because right ventricular weight increased only $26 \%$. NE uptake- 1 carrier sites may decrease in number either because of loss of adrenergic nerve fibers in the failing myocardium or because of a specific mechanism of NE uptake-1 carrier downregulation. It is not known whether the number of NE uptake-1 carrier sites can be regulated by concentrations of either synaptic NE or other neurotransmitters.

Decrease in tissue NE uptake alone probably is inadequate to increase synaptic NE and cause beta-receptor downregulation. Studies have shown that in hearts devoid of NE uptake function such as occurs after either surgical or pharmacological denervation (13), myocardial beta-receptor number either shows no changes $(38)$ or actually increases $(39,40)$.

Increased circulating NE is an index of heightened sympathetic tone, and has often been implicated to be the cause of beta-adrenergic subsensitivity and beta-adrenoceptor downregulation in congestive heart failure. However, circulating NE is not a precise measure of adrenergic synaptic NE directly surrounding beta-receptors. In tissues with a competent adrenergic neuronal uptake system, synaptic NE is taken up avidly by nerve endings and, even in the presence of excessive sympathetic stimulation, may not increase to a level sufficiently high to reduce beta-receptor number. In vitro studies have shown that beta-receptor downregulation by agonists occurs in a concentration-dependent, and time-dependent fashion $(41,42)$. The initial reaction after exposure to beta-agonists involves an uncoupling of beta-receptors from adenylate cyclase; reduction of cell surface beta-receptor number occurs later and only if a critically high agonist level is reached. In contrast, synaptic NE is expected to increase markedly after sympathetic stimulation in tissues with suppressed NE uptake. In our present study despite an increase in circulating NE levels, beta-receptor number was reduced only in the right ventricle, where a subnormal NE uptake activity was also documented. Neither the left ventricle nor the kidneys showed a depressed NE uptake activity or a reduction of beta-receptor number in RHF. This hypothesis is also consistent with the findings that myocardial beta-receptor number does not decrease after chronic intravenous administration of NE in normal dogs $(11,12)$.

Our study shows no significant correlation between right ventricular beta-receptor number and arterial NE concentration in RHF dogs. Likewise, Limas et al. (43) found no significant correlation between arterial NE and myocardial beta-receptor number in patients with moderate to severe congestive heart failure. The latter investigators, however, noted that the two variables correlated significantly in patients with mild to moderate heart failure. The relationship between plasma NE and myocardial beta-receptor number was also studied in patients with dilated cardiomyopathy (44). There was a weak correlation $(r=-0.42)$ between arterial NE and myocardial beta-receptor number, but a tighter correlation $(r=-0.64)$ existed between coronary sinus NE and myocardial beta-receptor, suggesting that changes of myocardial beta-receptor are causally related to cardiac-derived NE. Furthermore, using autoradiography, Murphree et al. (45) found that beta-receptor 
density was lower in the subendocardium than the subepicardium of tissue slices taken from patients with severe heart failure. This transmural gradation of beta-receptor density suggests that myocardial beta-receptor density is influenced by some local tissue factors. Further studies are warranted to determine whether NE uptake is more severely depressed, or whether interstitial NE is higher, in the subendocardial layer than the subepicardial layer.

$\mathrm{NE}$ was depleted in both the right and left ventricles of the RHF dogs. Similar results have been previously reported in human and experimental heart failure $(46,47)$. This change appears to be specific to the heart, because NE concentration did not change significantly in the renal cortex. The decrease in myocardial NE probably is caused, at least in part, by the defective NE uptake mechanism $(15,36)$. The lack of correlation between NE uptake activity and myocardial NE depletion in the left ventricles of RHF dogs in our present study, however, suggests that NE depletion cannot be accounted for by abnormal NE uptake alone. Alternatively, myocardial NE depletion could have resulted from decreased NE synthesis, as heart failure has been shown to be associated with a decrease in cardiac tyrosine hydroxylase activity (48-50), or other ratelimiting steps for cardiac NE synthesis (51).

The dissociation constant for $\left[{ }^{3} \mathrm{H}\right] \mathrm{DHA}$ did not change significantly in either the right ventricle or renal cortex with the development of RHF. However, the dissociation constant of myocardial beta-receptors was slightly greater in the left ventricle of the RHF dog than the sham-operated control. The significance of this small increase in dissociation constant is not known. However, in dogs with left ventricular failure produced by aortic constriction, a much greater increase in dissociation constant has been noted (52). An increase in dissociation constant also occurs after chronic administration of exogenous NE (12), and probably is caused by loss of high-affinity beta-receptors $(52,53)$.

Recently, the beta-receptor antagonist metoprolol has been found to increase lymphocyte and myocardial beta-receptor number in patients with congestive heart failure $(54,55)$, suggesting beta-receptor downregulation may be causally related to agonist stimulation. In addition, metoprolol therapy has been shown to improve patients' heart failure symptoms, exercise capacity, and left ventricular function $(56,57)$. Most of these studies, however, were conducted in a small number of patients and were not placebo controlled. The question whether beta-receptor blockade in congestive heart failure reverses myocardial beta-receptor downregulation and increases myocardial inotropic responses to adrenergic stimulation deserves further extensive studies.

In summary, the present study indicates that right ventricular beta-receptor density correlated with the number of tissue NE uptake-1 carrier sites. We also showed that the defect in NE uptake mechanism was found only in the failing right ventricle. This chamber-specific reduction of NE uptake carrier sites may be expected to increase synaptic NE concentration, particularly in the presence of excessive sympathetic stimulation, and to cause agonist-induced homologous desensitization. Our results further suggest that the lack of correlation between beta-receptor density and arterial NE concentration does not necessarily refute a role of agonist-induced homologous desensitization. Direct correlation between synaptic $\mathrm{NE}$ concentration and myocardial beta-receptor number is needed. Further experiments are warranted to determine whether the beta-receptor downregulation in heart failure is causally related to beta-agonist stimulation.

\section{Acknowledgments}

The authors thank Drs. J. Franklin Richeson, William B. Hood, Jr., and John R. Sladek, Jr. for their helpful advice, and constructive comments in the preparation of the manuscript. We also thank Mary Ann Evans, Lisa Guthinger, and Lynette Knapp for their expert assistance.

The study was supported in part by the Public Health Service grants HL-35194, and HL-39260 and a grant-in-aid from the American Heart Association.

\section{References}

1. Thomas, J. A., and B. H. Marks. 1978. Plasma norepinephrine in congestive heart failure. Am. J. Cardiol. 41:233-243.

2. Colucci, W. S., R. W. Alexander, G. H. Williams, R. E. Rude, B. L. Holman, M. A. Konstam, J. Wynne, G. H. Mudge, Jr., and E. Braunwald. 1981. Decreased lymphocyte beta-adrenergic-receptor density in patients with heart failure and tolerance to the beta-adrenergic agonist pirbuterol. $N$. Engl. J. Med. 305:185-190.

3. Francis, G. S., S. R. Goldsmith, and J. N. Cohn. 1982. Relationship of exercise capacity to resting left ventricular performance and basal plasma norepinephrine levels in patients with congestive heart failure. Am. Heart J. 104:725-731.

4. Wahr, D. W., K. Swedberg, M. Rabbino, M. J. Hoyle, D. Curran, W. W. Parmley, and K. Chatterjee. 1984. Intravenous and oral prenalterol in congestive heart failure: effects on systemic and coronary hemodynamics and myocardial catecholamine balance. Am. J. Med. 76:999-1005.

5. Swedberg, K., K. Chatterjee, M. Roizen, T. Ports, and W. Parmley. 1982. Myocardial norepinephrine release in congestive heart failure. Circulation. 66(Suppl. II):II-23. (Abstr.)

6. Bristow, M. R., R. Ginsburg, W. Minobe, R. S. Cubicciotti, W. S. Sageman, K. Lurie, M. E. Billingham, D. C. Harrison, and E. B. Stinson. 1982. Decreased catecholamine sensitivity and $\beta$-adrenergicreceptor density in failing human heart. $N$. Engl. J. Med. 307:205-211.

7. Fowler, M. B., J. A. Laser, G. L. Hopkins, W. Minobe, and M. R. Bristow. 1986. Assessment of the $\beta$-adrenergic receptor pathway in the intact failing human heart: progressive receptor down-regulation and subsensitivity to agonist response. Circulation. 74:1290-1302.

8. Harden, T. K. 1983. Agonist-induced desensitization of the $\beta$ adrenergic receptor-linked adenylate cyclase. Pharmacol. Rev. 35:5-32.

9. Lefkowitz, R. J., M. G. Caron, and G. L. Stiles. 1984. Mechanisms of membrane-receptor regulation. Biochemical, physiological and clinical insights derived from studies of the adrenergic receptors. N. Engl. J. Med. 310:1570-1579.

10. Sibley, D. R., and R. J. Lefkowitz. 1985. Molecular mechanisms of receptor desensitization using the $\beta$-adrenergic receptor-coupled adenylate cyclase system as a model. Nature (Lond.). 317:124129.

11. Raum, W. J., M. M. Laks, D. Garner, M. H. Ikuhara, and R. S. Swerdloff. 1984. Norepinephrine increases $\beta$-receptors and adenylate cyclase in canine myocardium. Am. J. Physiol. 246 (Heart Circ. Physiol. 15): $\mathrm{H} 31-\mathrm{H} 36$.

12. Vatner, D. E., S. F. Vatner, J. Nejima, N. Uemura, T. H. Hintze, R. M. Graham, and C. J. Homcy. 1988. A mechanism of catecholamine desensitization distal to the $\beta$-adrenergic receptor in the intact animal. Clin. Res. 36:605a. (Abstr.)

13. Vatner, D. E., S. F. Vatner, J. Nejima, N. Uemura, E. E. 
Susanni, T. H. Hintze, R. M. Graham, and C. J. Homcy. 1988. Role of cardiac nerves in desensitization. Circulation. 78(Suppl. II):II-164. (Abstr.)

14. Potter, L. T., T. Cooper, V. L. Willman, and D. E. Wolfe. 1965. Synthesis, binding, release, and metabolism of norepinephrine in normal and transplanted dog hearts. Circ. Res. 16:468-481.

15. Rose, C. P., J. H. Burgess, and D. Cousineau. 1985. Trace norepinephrine kinetics in coronary circulation of patients with heart failure secondary to chronic pressure and volume overload. J. Clin. Invest. 76:1740-1747.

16. Petch, M. C., and W. G. Nayler. 1979. Uptake of catecholamines by human cardiac muscle in vitro. Br. Heart J. 41:336-339.

17. Rose, C. P., J. H. Burgess, and D. Cousineau. 1983. Reduced aortocoronary sinus extraction of epinephrine in patients with left ventricular failure secondary to long-term pressure or volume overload. Circulation. 68:241-244.

18. Bristow, M. R., W. Minobe, R. Rasmussen, R. Ginsburg, M. Fowler, and P. Larrabee. 1985. Chamber-specific adrenergic abnormalities in isolated right ventricular failure in the human heart. Circulation. 72(Suppl. III):III-731. (Abstr.)

19. Fan, T.-H. M., C.-s. Liang, S. Kawashima, and S. P. Banerjee. 1987. Alterations in cardiac $\beta$-adrenoceptor responsiveness and adenylate cyclase system by congestive heart failure in dogs. Eur. J. Pharmacol. 140:123-132.

20. Higgins, C. B., R. Pavelec, and S. F. Vatner. Modified technique for production of experimental right-sided congestive heart failure. Cardiovasc. Res. 7:870-874.

21. Barger, A. C., B. B. Roe, and G. S. Richardson. 1952. Relation of valvular lesions and of exercise to auricular pressure, work tolerance, and to development of chronic, congestive failure in dogs. Am. J. Physiol. 169:384-399.

22. Davidson, D. M., J. W. Covell, C. I. Malloch, and J. Ross, Jr. 1974. Factors influencing indices of left ventricle contractility in conscious dogs. Cardiovasc. Res. 8:299-312.

23. Peuler, J. D., and G. A. Johnson. 1977. Simultaneous single isotope radioenzymatic assay of plasma norepinephrine, epinephrine and dopamine. Life Sci. 21:625-636.

24. Sharma, V. K., and S. P. Banerjee. 1977. Inhibition of $\left[{ }^{3} \mathrm{H}\right]-$ norepinephrine uptake in peripheral organs of some mammalian species by ouabain. Eur. J. Pharmacol. 41:417-429.

25. Lowry, O. H., N. J. Rosebrough, A. L. Farr, and R. J. Randall. 1951. Protein measurement with the Folin phenol reagent. J. Biol. Chem. 193:265-275.

26. Javitch, J. A., R. O. Blaustein, and S. H. Snyder. 1984. $\left[{ }^{3} \mathrm{H}\right]-$ Mazindol binding associated with neuronal dopamine and norepinephrine uptake sites. Mol. Pharmacol. 26:35-44.

27. Sundaresan, P. R., V. K. Sharma, S. I. Gingold, and S. P. Banerjee. 1984. Decreased beta-adrenergic receptors in rat heart in streptozotocin-induced diabetes: role of thyroid hormone. Endocrinology. 114:1358-1363.

28. Scatchard, G. 1949. The attractions of proteins for small molecules and ions. Ann. NY Acad. Sci. 51:660-672.

29. McPherson, G. A. 1985. Analysis of radioligand binding experiments: a collection of computer programs for the IBM PC. $J$. Pharmacol. Methods. 14:213-228.

30. Liang, C.-s., N. Imai, C. K. Stone, P. D. Woolf, S. Kawashima, and $R$. R. Tuttle. 1987. The role of endogenous opioids in congestive heart failure: Effects of nalmefene on systemic and regional hemodynamics in dogs. Circulation. 75:443-451.

31. Stone, C. K., C.-s. Liang, N. Imai, S. Sakamoto, C. D. Sladek, and W. B. Hood, Jr. 1988. Short-term hemodynamic effects of vasopressin $\mathrm{V}_{1}$-receptor inhibition in chronic right-sided congestive heart failure. Circulation. 78:1251-1259.

32. Higgins, C. B., S. F. Vatner, D. L. Eckberg, and E. Braunwald. 1972. Alterations in the baroreceptor reflex in conscious dogs with heart failure. J. Clin. Invest. 51:715-724.
33. Greenberg, T. T., W. H. Richmond, R. A. Stocking, P. D. Gupta, J. P. Meehan, and J. P. Henry. 1973. Impaired atrial receptor responses in dogs with heart failure due to tricuspid insufficiency and pulmonary artery stenosis. Circ. Res. 32:424-433.

34. Sakamoto, S., and C.-s. Liang. 1989. Opiate receptor inhibition improves the blunted baroreflex function in dogs with right-sided congestive heart failure. Circulation. In press.

35. Sachs, C. 1970. Noradrenaline uptake mechanisms in the mouse atrium. Acta Physiol. Scand. 79(Suppl. 341):1-67.

36. Spann, J. F., Jr., C. A. Chidsey, P. E. Pool, and E. Braunwald. 1965. Mechanism of norepinephrine depletion in experimental heart failure produced by aortic constriction in the guinea pig. Circ. Res. 17:312-321

37. Bristow, M. R., R. Ginsburg, V. Umans, M. Fowler, W. Minobe, R. Rasmussen, P. Zera, R. Menlove, P. Shah, S. Jamieson, and E. B. Stinson. 1986. $\beta_{1}$ - and $\beta_{2}$-Adrenergic-receptor subpopulations in nonfailing and failing human ventricular myocardium: coupling of both receptor subtypes to muscle contraction and selective $\beta_{1}$-receptor down-regulation in heart failure. Circ. Res. 59:297-309.

38. Denniss, A. R., J. D. Marsh, R. J. Quigg, J. B. Gordon, and W. S. Colucci. 1989. $\beta$-Adrenergic receptor number and adenylate cyclase function in the denervated transplanted and cardiomyopathic heart. Circulation. 79:1028-1034.

39. Glaubiger, G., B. S. Tsai, R. J. Lefkowitz, B. Weiss, and E. M. Johnson, Jr. 1978. Chronic guanethidine treatment increases cardiac beta adrenergic receptors. Nature (Lond.). 273:240-242.

40. Vatner, D. E., M. Lavellee, J. Amano, A. Finizola, C. J. Homcy, and S. F. Vatner. 1985. Mechanisms of supersensitivity to sympathomimetic amines in the chronically denervated heart of the conscious dog. Circ. Res. 57:55-64.

41. Krall, J. F., M. Connelly, and M. L. Tuck. 1980. Acute regulation of beta adrenergic catecholamine sensitivity in human lymphocytes. J. Pharmacol. Exp. Ther. 214:554-560.

42. Insel, P. A., L. C. Mahan, H. J. Motulsky, L. M. Stoolman, and A. M. Koachman. 1983. Time-dependent decreases in binding affinity of agonists for beta-adrenergic receptors of intact S49 lymphoma cells: a mechanism of desensitization. J. Biol. Chem. 258:13597-13605.

43. Limas, C. J., I. F. Goldenberg, and G. Pierpont. 1988. Intracellular $\beta$-adrenergic distribution in the failing human myocardium. $J$. Am. Coll. Cardiol. 11:117A. (Abstr.)

44. Sandoval, A., E. M. Gilbert, R. Ginsburg, R. Rasmussen, W. Minobe, P. Larrabee, and M. R. Bristow. 1988. Is $\beta_{1}$ receptor downregulation in the failing human heart the result of exposure to cardiacderived norepinephrine? J. Am. Coll. Cardiol. 11:117A. (Abstr.)

45. Murphree, S. S., T. K. Tolley, and J. E. Saffitz. 1988. The distribution of $\beta$-adrenergic receptor in failing human myocardium: Implications for mechanisms of down-regulation. J. Am. Coll. Cardiol. 11:116A. (Abstr.)

46. Chidsey, C. A., G. A. Kaiser, E. H. Sonnenblick, J. F. Spann, and E. Braunwald. 1964. Cardiac norepinephrine stores in experimental heart failure in the dog. J. Clin. Invest. 43:2386-2393.

47. Chidsey, C. A., E. Braunwald, and A. G. Morrow. 1965. Catecholamine excretion and cardiac stores of norepinephrine in congestive heart failure. Am. J. Med. 39:442-451.

48. Poole, P. E., J. W. Covell, M. Levitt, J. Gibb, and E. Braunwald. 1967. Reduction of cardiac tyrosine hydroxylase activity in experimental congestive heart failure. Circ. Res. 20:349-353.

49. Sassa, H. 1971. Mechanism of myocardial catecholamine depletion in cardiac hypertrophy and failure in rabbits. Jpn. Circ. J. 35:391-403.

50. Schmid, P. G., D. D. Lund, and R. Roskoski, Jr. 1981. Efferent autonomic dysfunction in heart failure. In Disturbances in Neurogenic Control of the Circulation. F. M. Abboud, H. A. Fozzard, J. P. Gilmore, D. J. Reis, editors. American Physiological Society, Bethesda, MD. 33-49.

51. Sole, M. J., A. B. Kamble, and M. N. Hussain. 1977. A possible 
change in the rate-limiting step for cardiac norepinephrine synthesis in the cardiomyopathic Syrian hamster. Circ. Res. 41:814-817.

52. Vatner, D. E., S. F. Vatner, A. M. Fuji, and C. J. Homcy. 1985. Loss of high affinity cardiac beta adrenergic receptors in dogs with heart failure. J. Clin. Invest. 76:2259-2264.

53. Longabaugh, J. P., D. E. Vatner, S. F. Vatner, and C. J. Homcy. 1988. Decreased stimulatory guanosine triphosphate binding protein in dogs with pressure-overload left ventricular failure. J. Clin. Invest. 81:420-424.

54. Heilbrunn, S. M., P. Shah, M. R. Bristow, H. A. Valentine, R. Ginsburg, and M. B. Fowler. 1989. Increased $\beta$-receptor density and improved hemodynamic response to catecholamine stimulation dur- ing long-term metoprolol therapy in heart failure from dilated cardiomyopathy. Circulation. 79:483-490.

55. Eisenger, M. R., R. S. Englemeier, N. J. Rad, M. E. Grace, and P. J. Scanlon. 1987. Increase in cardiac function and lymphocyte beta-adrenergic receptor density in dilated cardiomyopathy patients treated with metoprolol. Circulation. 76(Suppl. IV):IV-308. (Abstr.)

56. Currie, P. J., M. J. Kelly, A. McKenzie, R. W. Harper, Y. L. Lim, J. Federman, S. T. Anderson, and A. Pitt. 1984. Oral beta-adrenergic blockade with metoprolol in chronic severe dilated cardiomyopathy. J. Am. Coll. Cardiol. 3:203-209.

57. Shanes, J. G. 1987. $\beta$-Blockade-rational or irrational therapy for congestive heart failure? Circulation. 76:971-973. 